\title{
Organizational Factors Affecting E-commerce Adoption in Small and Medium-sized Enterprises
}

\author{
R.P.I.R. Senarathna and H.V.A. Wickramasuriya ${ }^{1 *}$ \\ Department of Industrial Management \\ Faculty of Applied Sciences, Wayamba University of Sri Lanka \\ Kuliyapitiya, Sri Lanka
}

\begin{abstract}
The use of e-commerce in SMEs has become an important topic in information systems research. Despite the enormous attention given to encourage SMEs to adopt e-commerce by governments, research undertaken to identify strategies of e-commerce adoption for SMEs in developing countries, especially in Sri Lanka is minimal. The primary objective of this study was to examine the relationship between organizational factors and ecommerce adoption to understand the factors that contribute to e-commerce adoption. Quantitative approaches were considered in this research. The study draws on the data obtained from a sample of 200 SMEs in Colombo District using a postal survey. The sample was chosen using a stratified random sampling technique based on business type of the SMEs. Based on correlation, regression and cluster analysis, the findings of this research were revealing and facilitated the understanding of certain organizational factors that influence the level of e-commerce adoption. The main factor identified was organizational culture. The results of this study show empirical evidence that there is a positive correlation between the adhocracy cultural characteristics among the SMEs and the level of e-commerce adoption. Also, hierarchy cultural characteristic showed a negative correlation with the level of e-commerce adoption in SMEs. An argument can be made out that a culture promoting innovation and risk acceptance would provide the needed support for higher levels of adoption of new technologies. Top managers' opinion towards innovation also influences the way of doing business by the firm.
\end{abstract}

Key words: e-commerce, e-commerce adoption, internet, organizational culture, Small and Medium-sized Enterprises (SMEs).

\section{INTRODUCTION}

Electronic commerce is one of the most discussed topics in business today. It is already leading to the reshaping of customer and supplier relationships, the streamlining of business processes and, in some cases, even the restructuring of whole industries. E-commerce is beneficial to both businesses and consumers by removing time and space barriers. For modern enterprises, the value of information technology is multi-faceted, such as improving product variety, quality, and customer satisfaction, facilitating administrative processes, reducing cost, enriching labor and management productivity, and enhancing a competitive advantage.

To whom correspondence should be addressed: heshan54@gmail.com Department of Agricultural Extension, Faculty of Agriculture, University of Peradeniya, Peradeniya Sri Lanka. 
Small and Medium-sized Enterprises (SMEs), vital to the economy in any country, are very often recognized as an economy growth engine. They often occupy strategic positions in the economy. The SME sector plays a significant role in its contribution to the national economy in terms of the wealth created and the number of people employed in Sri Lanka. The SMEs in Sri Lanka perform a strategic role by accounting for a very high percentage of the total number of business establishments. While the domestic market is the main outlet for SMEs in Sri Lanka, they make a significant contribution towards exports. Although direct exports from this sector may not be large, SMEs play an important role as indirect exporters. There are a large number of SMEs that manufacture export products, or parts, with larger entrepreneurs coordinating such arrangements and handling the direct exports. Even though there is now an interesting and growing number of studies addressing e-commerce adoption within the specific context of SMEs (for example Chen et al, 2008; Kapurubandara et al, 2008 and Scupola, 2009), not much research has been conducted in developing countries, especially Sri Lanka, in relation to ICT and e-commerce adoption. The primary objective of this study was to examine the relationship between the organizational factors and ecommerce adoption to understand the factors that contribute to e-commerce adoption.

\section{Conceptual framework}

The literature review provided a conceptual framework for this study. The organizational context represents the factors internal to an organization that influence innovation adoption. Variables that might influence e-commerce adoption are organizational culture (Nickels et al, 2008), technological resources and top managers' attitudes (Poon and Swatman, 1999). The organizations were grouped based on their e-commerce adoption levels and labeled as Developers/Searchers, Communicators, Web presence and Transactors. Thus, a model of ecommerce adoption in Small and Medium-sized Enterprises can therefore be conceptualized as given in Figure1:

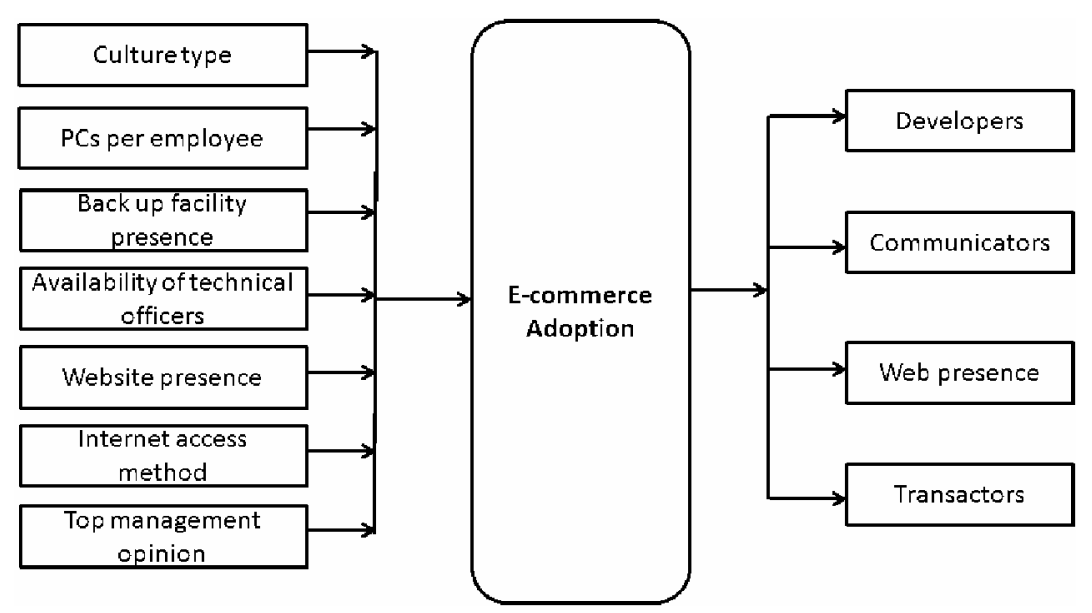

Fig. 1. Research Model 


\section{METHODOLOGY}

Survey instrument: The primary objective of this study is to identify the relationship between organizational culture type and the level of e-commerce adoption. So, a cross-sectional approach was considered in this research. A mailed questionnaire was developed with the aim of covering the basic research objectives. The questionnaire was divided into four sections. Section one captured the data about the demographic profile and section two covered the information about technological resources and view of management for use of computers and information systems. Section three measured the extent of e-commerce adoption. Section four was used to measure the prevailing organizational culture in each participating organization.

\section{Organizational culture}

The Organizational Culture Assessment Instrument (OCAI) by Cameron and Quinn (1999) was used to measure the prevailing organizational culture in each participating organization. For identifying the levels of the four major culture types (Clan, Adhocracy, Market, and Hierarchy), the OCAI provides four scores that can be used to plot the perceptions of culture of the organizations. In each question, respondents were asked to assign a total of 100 points among four alternatives describing the characteristics of their organization. The four scores are calculated from the collective results of the six questions in the OCAI. Each of the four scores indicates the collective perception of organizations completing the instrument, regarding the strength of the four culture types.

\section{Level of e-commerce adoption}

In accordance with White et al. (1998) adoption is measured according to business activities undertaken on-line, rather than the technology features. In order to measure the adoption activities, the corresponding activity descriptions were internal communication between employees, communication (email) with customers or suppliers, external information search, e.g. competitors, regulations, providing information about the company online, providing information about goods or services online, advertising online, document exchange with customers or suppliers, recruitment online, communication with shareholders and investors, receiving payments online, after sales service or contact online, taking orders online, identify new inventory suppliers online, ordering and payment of inventory purchasing online, non inventory purchasing (such as travel, stationery), and delivery of digital goods or services online. Respondents were asked to indicate whether they 'currently use', 'did not use' or 'planned to use' each activity.

Data collection The population of this study consisted of SMEs in Colombo District. Prior to the actual field survey, a sampling frame was acquired which comprised of the current list of registered members with the National Chamber of Commerce of Sri Lanka. The sample for this study was then chosen using a stratified random sampling technique based on business type (such as Manufacturing and Services) of the SMEs. A total of 200 SMEs were chosen.

Data analysis In this paper some descriptive statistics were used to explain the empirical data. Some common statistical approaches such as mean and standard deviation were used for this purpose. For clarifying the influence of organizational culture and technological resources on e-commerce adoption, cluster analysis was used to group organizations based on level of ecommerce adoption. The cluster analysis was carried out on the responses using the complete 
set of activity variables. Clustering was carried out with three, four and five clusters and the cubic cluster criteria generated for each. A large increase in this measure at the four cluster level suggested the suitability of a four cluster solution. The four cluster solution also met a secondary criterion that there is sufficient number of cases in each cluster to allow statistical analysis.

\section{RESULTS AND DISCUSSION}

Sample characteristics of the study: The Sample characteristics (Table 1) showed that $53.1 \%$ of firms had fewer than 50 employees, and $46.9 \%$ had between 50 and 249 employees.

Table 1. Sample characteristics of the study

\begin{tabular}{lccc}
\hline Legal form of the Organization & Percentage & Industry & Percentage \\
\hline Private & 77.8 & Services & 22.2 \\
Partnership & 14.8 & Export & 19.8 \\
Sole proprietor & 6.2 & Import & 18.5 \\
Public & 1.2 & Manufacturing & 17.3 \\
Number of employees & Percentage & Trading & 14.8 \\
$<50$ (Small) & 53.1 & Other & 7.4 \\
$50-249$ (Medium) & 46.9 & & \\
\hline
\end{tabular}

Reviewing the firms' activities, in general terms $22.2 \%$ were service sector, $19.8 \%$ were export and $18.5 \%$ were in the import sector. The manufacturing enterprises (17.3\%), trading enterprises (14.8\%) and other enterprises (7.4\%) represented the rest of the respondents. Most of the respondent firms' legal forms were private $(77.8 \%)$, and rest of the forms were partnership (14.8\%), sole proprietor $(6.2 \%)$ and public (1.2\%).

E-commerce adoption levels Clustering was carried out with three, four and five clusters and the cubic cluster criteria generated for each. A large increase in this measure at the four cluster level suggested the suitability of a four cluster solution. In order to identify the adoption characteristics of the four clusters a cross-tabulation of the responses by cluster for each activity was generated. In cluster 1 (Developers/Searchers) companies had the lowest levels of operational e-commerce services, but had the highest level of external information search. They are therefore referred to here as a 'searcher', i.e.companies who are at the very start of their e-commerce adoption and are currently searching business information. The Companies in cluster 2 (Communicators) were making extensive use of email to communicate with customers and suppliers, and the web to find business information. They were also frequently using email for electronically exchanging documents and designs with customers and suppliers. In Cluster 3 (Web Presence) companies were undertaking all of the activities currently being undertaken by companies in cluster 2 . They were also operating the services that cluster 2 companies were still currently developing. The companies in cluster 4 (Transactors) were found to be undertaking all of the activities undertaken by cluster 3 companies but in addition they were found to be identifying new inventory suppliers on-line, ordering and payment of inventory purchasing on-line, receiving payments on-line, providing after sales service or contact, undertaking recruitment on-line, and taking orders on-line. The findings also suggest that the four clusters identified represent a set of sequential stages through which SMEs pass when adopting e-commerce. Further support of the stage model is 
provided if the set of e-commerce activities can be used to create a numerical scale of adoption (ADOPTSCALE). The findings of the analysis for each adoption are presented in Table 2. It can be seen that firms in each duster have a progressively higher level of ecommerce adoption, and the $\mathrm{F}$ test $(3,77)=214.734$, $\mathrm{p}<.05$ was significant. It implies that each cluster is significantly different in terms of e-commerce adoption.

Table 2. Adoption scale by cluster

\begin{tabular}{lccccc}
\hline Adoptscale & $\begin{array}{c}\text { Cluster 1 } \\
(\mathbf{N}=\mathbf{1 3})\end{array}$ & $\begin{array}{c}\text { Cluster 2 } \\
(\mathbf{N = 3 8})\end{array}$ & $\begin{array}{c}\text { Cluster 3 } \\
(\mathbf{N = 2 2})\end{array}$ & $\begin{array}{c}\text { Cluster 4 } \\
(\mathbf{N}=\mathbf{8})\end{array}$ & $\begin{array}{c}\text { F statistic } \\
(\mathbf{p} \text { value) }\end{array}$ \\
\hline Mean & 4.39 & 13.45 & 19.45 & 27.12 & 214.734 \\
Std Dev & 2.50 & 2.25 & 1.87 & 2.47 & .000 \\
\hline
\end{tabular}

Amongst the four prevailing culture types, Adhocracy culture type was significantly and positively correlated with e-commerce adoption $(\mathrm{r}=.687, \mathrm{p}<0.01)$. Also, Hierarchy culture type was significantly and negatively correlated with e-commerce adoption $(r=-.702$, $\mathrm{p}<0.01$ ). The other two types of cultures, i.e. Clan and Market, were not significantly correlated with e-commerce adoption (Table 3). As expected the top managers opinion was significantly and positively correlated with e-commerce adoption $(r=.483, p<0.01)$. The top managers opinion was also significantly and positively correlated with adhocracy culture $(\mathrm{r}=.404, \mathrm{p}<0.01)$. On the contrary, the top managers opinion was significantly and negatively correlated with hierarchy culture $(\mathrm{r}=-.497, \mathrm{p}<0.01)$.

Table 3. Correlation matrix

\begin{tabular}{lrrrrr}
\hline & e-com & \multicolumn{1}{c}{ Clan } & Adhocracy & Market & Hierarchy \\
\hline Clan & .122 & & & & \\
Adhocracy & $.687(* *)$ & -.038 & & & \\
Market & -.149 & $-.539(* *)$ & $-.282\left(^{*}\right)$ & & \\
Hierarchy & $-.702(* *)$ & $-.247(*)$ & $-.856\left(^{* *}\right)$ & .059 & \\
Website & $.548\left(^{* *}\right)$ & .056 & $.474\left(^{* *}\right)$ & -.124 & $-.455(* *)$ \\
Top mgt support & $.483(* *)$ & .118 & $.404(* *)$ & .010 & $-.497\left(^{* *}\right)$ \\
Employees & $.312(* *)$ & -.043 & $.280\left(^{*}\right)$ & .022 & $-.283\left(^{*}\right)$ \\
\hline
\end{tabular}

** Correlation is significant at the 0.01 level (2-tailed).

* Correlation is significant at the 0.05 level (2-tailed).

The regression model for e-commerce adoption is presented in Table 4. The association between the dependent and independent variables can be explained by the coefficient of determination $\left(r^{2}\right)$. The value of the coefficient of determination $\left(r^{2}\right)$ is 0.63 which implies that $63 \%$ of observed variability in e-commerce adoption can be explained by the organizational factors represented in the model. An Analysis of Variance (ANOVA) F (3, $77)=31.967, \mathrm{p}<0.01$, indicated that the model was significant, and thus supports the hypothesis that organizational factors are positively related to e-commerce adoption. 
Table 4. Relationships of Organizational factors with e-commerce adoption

\begin{tabular}{lrcccc}
\hline \multirow{2}{*}{ Model } & \multicolumn{2}{c}{$\begin{array}{c}\text { Un standardized } \\
\text { coefficients }\end{array}$} & $\begin{array}{c}\text { Standardized } \\
\text { coefficients }\end{array}$ & \multirow{2}{*}{ T } & Sig. \\
\cline { 2 - 4 } & \multicolumn{1}{c}{ B } & Std. Error & Beta & & \\
\hline (Constant) & -2.339 & 2.376 & & -.984 & .328 \\
Website & 2.757 & 1.215 & .188 & 2.268 & .026 \\
Adhocracy & .259 & .046 & .467 & 5.601 & .000 \\
Top managers opinion & 2.136 & .767 & .218 & 2.787 & .007 \\
\hline
\end{tabular}

$(\mathrm{p}<0.05, \mathrm{R}$ square $=.627, \mathrm{~F}=31.967 \mathrm{df}=3,77)$

Adhocracy culture showed a significant result with a beta weight of 0.47 . This positive relationship of adhocracy culture and e-commerce adoption was significant $(\mathrm{p}<0.01)$. Although the importance of organizational culture has been shown across multiple studies of e-commerce adoption, previously no study identified the specific characteristics of organizational culture that would best support e-commerce adoption.

This research shows the importance of the top managers' opinion towards innovation to promote innovation, risk-taking, and flexibility. A dynamic website, rather than a static one is capable of supporting more e-commerce activities on line enabling a higher level of ecommerce adoption. Thus, only possessing technological resources and infrastructure is not adequate to adopt e-commerce.

\section{CONCLUSIONS}

Although the importance of organizational culture has been implied in many studies of ecommerce adoption, no studies specifically identifying the characteristics of organizational culture that would best support e-commerce adoption were found in the literature review for this study. The results of this study showed empirical evidence that there is a positive correlation between the adhocracy cultural characteristics among the SMEs and the level of e-commerce adoption. Also a hierarchy cultural characteristic showed a negative correlation with the level of e-commerce adoption in SMEs. The top managers' opinion towards innovation showed a positive relationship with e-commerce adoption. Top managers' opinion towards innovation influences the way of doing business by the firm. Having personal computers had not had an impact on e-commerce adoption. E-commerce is not about technology but about a new way of treating customers and suppliers. A dynamic website, rather than a static one is capable of enabling more e-commerce activities, or enabling a higher level of e-commerce adoption. E-commerce is a paradigm shift that is radically changing traditional ways of doing business. Therefore, it is fundamental to change the mindset of management to a dynamic way of doing business. In practice, due to the significant impacts of the organizational factors on the adoption of e-commerce that have been identified here, the SME managers should determine the most effective measures to take in order to advance and promote the adoption, and the degree of use, of e-commerce in SMEs in Sri Lanka. 


\section{REFERENCES}

Cameron, K., and Quinn, R. (1999). Diagnosing and changing organizational culture: Based on the competing values framework. Addison-Wesley, Reading, MA.

Chen, J., and McQueen, R. (2008). Factors Affecting E-Commerce Stages of Growth in Small Chineese Firms in New Zealand: An analysis of Adoption Motivators and Inhibitors. J. of Glob. Info. Mgt. 16(1), 26-60.

Kapurubandara, M., and Lawson, R. (2008). Availability of E-commerce Support for SMEs in Developing Countries. The Int. J. on Adv. in ICT for Emerging Regions, 3-11.

Nickels, D. W., Kwun, O., and Omar, A. (2008). The effect of organizational culture on ecommerce adoption.

Poon, S., and Swatman, P. M. (1999). An exploratory study of small business Internet commerce issues, Info. Mgt. 35(1), pp. 9-18.

Scupola, A. (2009). SMEs' e-commerce adoption: perspectives from Denmark and Australia. Journal of Enterprise Info. Mgt. 22,152 - 166. 